\title{
Landslide Zone Investigation by Determining Cracks and Cracks Compressive Strength Test in Waru District, Pamekasan Regency
}

\author{
Sandy Vikki Ariyanto*, and Idon Joni \\ Department of Informatics Engineering, Faculty of Engineering, University of Madura, East Java, J1 Raya \\ Panglegur Km. 3,5 Pamekasan 69317, Madura, East Java, Indonesia \\ *Email: sandy@unira.ac.id
}

\begin{abstract}
Landslide zone investigation has been conducted using geoelectricity to determine the number of cracks and using a compressive strength test to determine compressive strength cracks. The result of this research is that the rock layers of Waru District consist of soil layers resulting from the weathering of quartz rock into quartz sandstone. This quartz sandstone lies on top of a more solid rock layer. The type of landslide that is formed in the Waru sub-district is translational. This type of landslide is caused by water entering the lower layer, causing landslides and the number of cracks that trigger landslides. The results of the low compressive strength test resulted in landslides. This result was due to a decrease in the number of pores filled with water and an increase in the pores that were not filled with water. This occurs due to the presence of water in the cracks, the number of cracks cavities, and the density of the cracks which results in reduced adhesion between the cracks holding layers.
\end{abstract}

Keywords: Landslide Zone, Cracks, Compressive Strength, Pamekasan

\section{INTRODUCTION}

Landslides cause material and non-material damage to the community. Landslides are natural disasters that often occur during the rainy season. These disasters usually cause considerable economic losses and casualties ${ }^{[1]}$. Landslides in Malalak District have caused casualties and the closure of the Malalak road section ${ }^{[2]}$. Therefore, it is necessary to research to monitor these landslides. To monitor these landslides, field measurements are required. The description of the researchers above has explained that the occurrence of landslides is very dangerous for the community in material and non-material damage and the psychology of the community is disturbed, therefore intensive monitoring is needed to minimize the occurrence of landslides.

It has been shown that it is very important to take field measurements after the dry season [3]. For this reason, it is better if the measurement is done during the dry season. Several geophysical studies have been realized in the last 10 years, complemented by permanent hydrogeological and geochemical monitoring at certain locations inside and outside of landslides ${ }^{[4]}$. Electrical resistivity tomography (ERT) can describe two types of faulty surface geometry (surface landslides and collapsed surfaces), and identifies three external shapes in ancient river basins, landslide bodies and collapse bodies ${ }^{[5]}$. The ERT method seeks to register and present variations in the properties of basic geotechnical materials in dams such as; bulk density, moisture content, elasticity, rock mechanical properties, electrical resistance and mineralogical and magnetic properties, and so on ${ }^{[6]}$. The objective of the ERT survey is to characterize the geometry of the landslide section ${ }^{[7]}$. Seismic and geoelectric methods are powerful tools for investigating landslides ${ }^{[8]}$. The 
description above explains that geophysical measurements can monitor the occurrence of landslides, therefore researchers use the geophysical measurement method. To minimize the occurrence of landslides that cause loss of both material and non-material. In geophysical measurements to maximize measurements, measurements are needed during the dry season, because at least water enters the ground during the dry season.

From the results of XRD, XRF, and SEM analysis, it is the occurrence of landslides due to almost cuboid crystals with high porosity, this occurs because there are many cavities in the soil resulting in the density of sand that is still lacking so that the soil is easily displaced. However, this data is still not sufficient to predict soil strength, so it is necessary to add data with civil engineering science. Additional data with the cracks compression test was carried out in 2020.

\section{METHOD}

The Geoelectric Survey to determine cracks and the compressive strength test for cracks was carried out in the Waru sub-district. This research was carried out with a combination of 2 science, namely geophysics and civil engineering from May to October 2020.

Geoelectric data acquisition using 64 channel geoelectric tools in one stretch with a spacing of 10 meters per point and using res2div for modeling. Data collection design in 2020 (Figure 1).

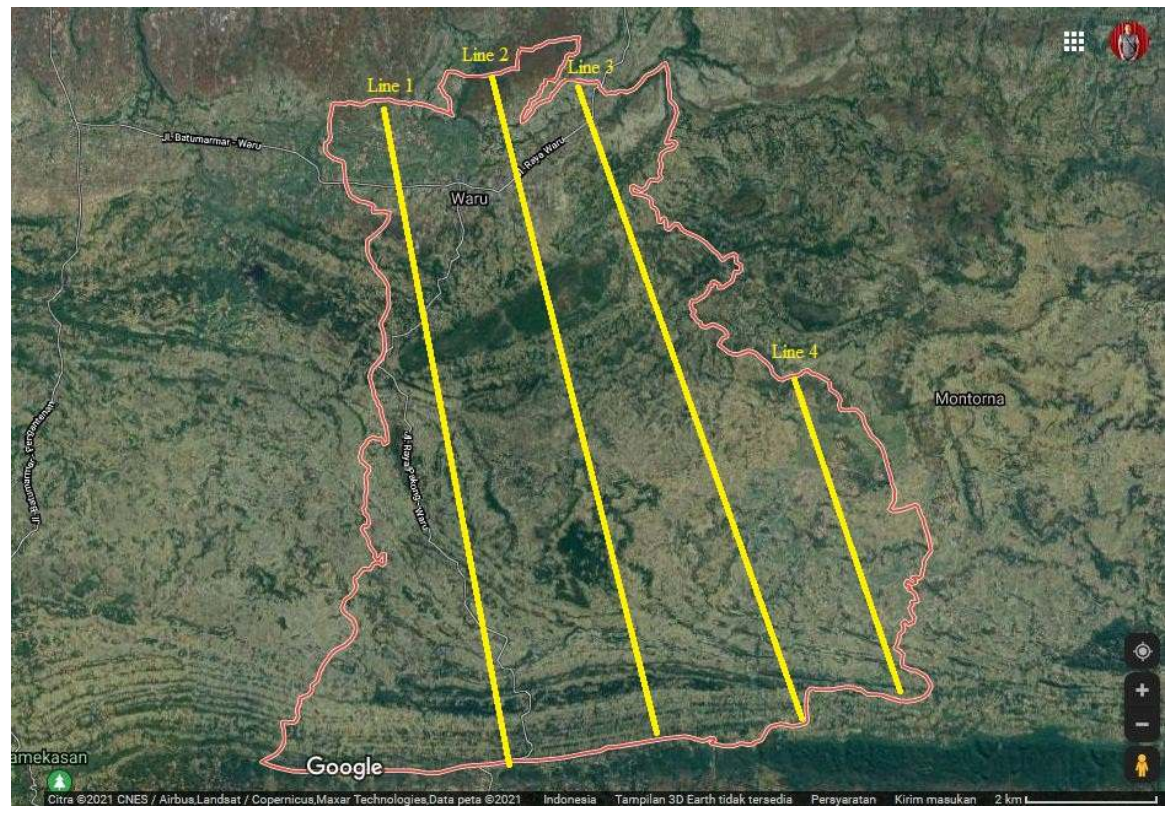

Figure 1.Geoelectric data acquisition design 2020

We sampled the soil to determine the compressive strength at the depth of these cracks to determine the compressive strength of cracks was carried out by taking samples of soil at the depth of these cracks. The soil sampling tool uses drilling, after taking a new sample the cracks strength test is carried out in the Civil Engineering Laboratory of the University of Madura.

\section{RESULTS AND DISCUSSION}

The results from the $2 \mathrm{D}$ appearance show that the rock resistivity value Line 1 to line 4 is in the range $51.2-396 \Omega \mathrm{m}$. The resistivity value of line 1 rocks yields $51.2-281 \Omega \mathrm{m}$ with an error value of $5.9 \%$. The resistivity value of line 2 rocks results in $71-231 \Omega \mathrm{m}$ with an 
error value of $2.7 \%$. The resistivity value of line 3 rocks produces $65-365 \Omega \mathrm{m}$ with an error value of $2.6 \%$. The resistivity value of line 4 rocks produces $54-376 \Omega \mathrm{m}$ with an error value of $2.9 \%$ (Figure 2 ).

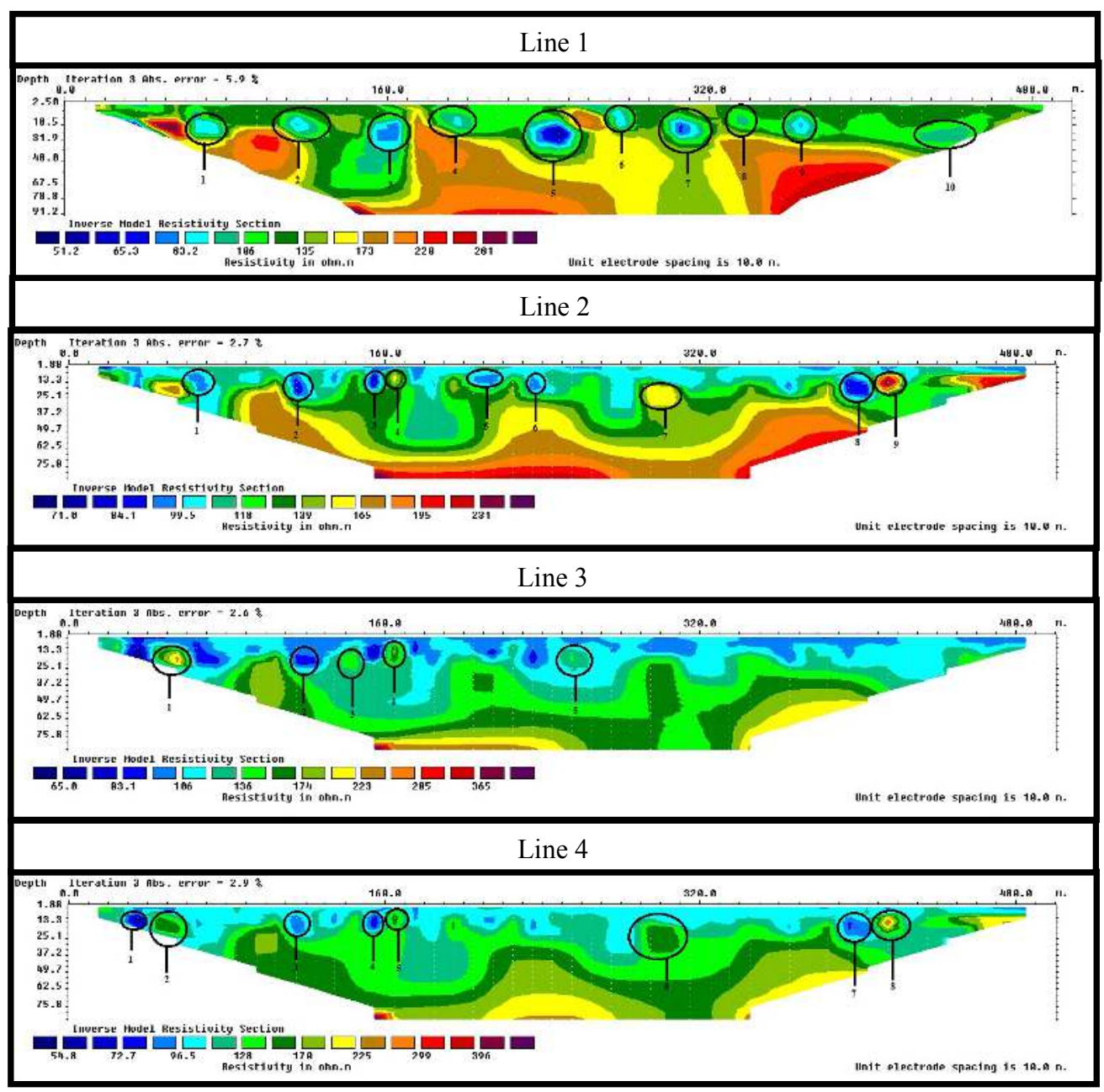

Figure 2. Resistivity results in geoelectric data in 2020 to look for cracks

The results of the geoelectric section reveal that the rock layer in Waru District consists of a layer of soil from weathering of quartz rock, which becomes quartz sandstone with a thickness of $4-15 \mathrm{~m}$ above a more solid rock layer. The intersection of the rock between the top and bottom soil layers is a sliding plane that is formed fairly evenly in each Line. In all lines, the landslide type that is formed is a translational type caused by water entering the lower layer so that landslides occur. Incoherent landslides, the shape, and structure of the soil are unstable or the rock mass remains intact during the landslide ${ }^{[10]}$. Overall, landslides in the Gombel Hill area can be found at a depth of $5 \mathrm{~m}-6 \mathrm{~m}$ and are found at the contact between the clay and clay rock layers ${ }^{[11]}$.

The rubble material in the 4 Lines consists of weathered soil formed from intersections of quartz sandstone, claystone, and other rock fragments mixed with water. This fracture structure is a weak zone that makes it easy for rainwater to seep into the ground. The-clay type soil material has a loose formation (unconsolidated material) so it is relatively unstable and if there is a disturbance to its structure, the bonds between the grains are easy to break. Where clay rock has a permeability value of 0.0004 , it easily passes water, while 
its porosity has a value of $40 \%$. The type resistance of a material depends on the porosity of the rock and the type of fluid filling the rock pores. A porous rock is easily filled with liquid so that the grains are easy to escape. Landslide potential zone where the physical properties of claystone easily derail massive material on it ${ }^{[12]}$. It was found that creeping was caused by excess soil mass from the top of the hill as well as an abundance of water which then resulted in reduced layer cohesion, increased load, and the absence of strong bulkheads to stop them [13]. Resistivity values at 10.3-40 clays and sandstones that experience rainwater intrusion. Massive sandstone and claystone layers with a resistivity value of $40-70 \mathrm{~m}^{[14]}$.

To identify possible landslide triggering events is to identify using rainfall ${ }^{[15]}$. If the rain continues in the Waru sub-district, the water contained in the soil will continue to increase and one day it becomes saturated with water, so that the holding capacity of the soil decreases, as a result, the land shifts and moves in the direction of the slope. Water that accumulates from high rainfall results in unbalanced cracks. If the cracks accumulate by water, it will be very dangerous because the load will get heavier below the surface which at any time can trigger landslides [9]. Three landslide susceptibility zones, namely low, high, and very high landslide susceptibility, have been described, landslide zones that result in very high landslide vulnerability due to rainfall ${ }^{[16]}$. Shallow landslides due to rain are the main landslide type occurring on the natural plains of Hong Kong due to the high seasonal rainfall and the soil profile that is resistant to deep weather ${ }^{[17]}$. The number of cracks on line 1 is in a stretch of 60 meters 450 meters totaling 10 cracks. On line 2 there is a stretch of 40 meters-320 meters as many as 9 cracks. On line 3 , there are 5 cracks in the 50-260 meter stretch. On line 4 there is a stretch of 30 meters- 310 meters as many as 8 cracks.

The results of the compressive test on the cracks zone were carried out to determine how long the cracks withstand rainwater. The way to do a pressure test is to take samples in the 4 lines with a variation of 3 samples. The results of the cracks can be seen in Table 1 .

Table 1.The results of the compressive strength test on cracks

\begin{tabular}{cccccc}
\hline No & Line & $\begin{array}{c}\text { Cracks } \\
\text { Number }\end{array}$ & $\begin{array}{c}\text { Cracks Thickness } \\
\text { (Meter) }\end{array}$ & $\begin{array}{c}\text { Depth of Cracks } \\
\text { (Meters) }\end{array}$ & $\begin{array}{c}\text { Cracks Compressive } \\
\text { Strength Test (MPa) }\end{array}$ \\
\hline 1 & & Cracks 6 & 3,2 & $2,5-18,5$ & 21,4 \\
2 & Line 1 & Cracks 8 & 2,8 & $8,5-17,6$ & 26,9 \\
3 & & Cracks 9 & 6,1 & $9,3-22,7$ & 22,6 \\
\hline 4 & & Cracks 1 & 10,7 & $2,3-20,9$ & 18,3 \\
5 & Line 2 & Cracks 4 & 4,9 & $1,9-10,4$ & 37,3 \\
6 & & Cracks 5 & 17,6 & $5,7-17,9$ & 20,7 \\
\hline 7 & & Cracks 1 & 15,3 & $7,8-19,4$ & 34,8 \\
8 & Line 3 & Cracks 3 & 8,5 & $8,3-20,7$ & 25,8 \\
9 & & Cracks 4 & 14,2 & $3,9-12,1$ & 29,3 \\
\hline 10 & & Cracks 1 & 11,8 & $3,5-14,7$ & 16,2 \\
11 & Line 4 & Cracks 5 & 7,4 & $1,8-11,3$ & 27,5 \\
12 & & Cracks 8 & 11,3 & $2,9-23,1$ & 31,7 \\
\hline
\end{tabular}


From the results of 3 samples of compressive strength test on line 1, the weak are cracks number 6 with a compressive strength value of $21.4 \mathrm{MPa}$ and cracks number 8 the strongest with a compressive strength value of $26.9 \mathrm{MPa}$, On line 2 the weakest cracks are number 1 with a compressive strength value of $18.3 \mathrm{MPa}$ and cracks number 4 is the strongest with a value compressive strength $37.3 \mathrm{MPa}$, weak line 3 is cracks number 3 with a compressive strength value of $25.8 \mathrm{MPa}$ and crack number 1 is the strongest with a compressive strength value $34.8 \mathrm{MPa}$, line 4 is weak is cracks number 1 with a strong value the pressure is $16.2 \mathrm{MPa}$ and cracks number 8 is the strongest with a compressive strength value of $31.7 \mathrm{MPa}$. This result was due to a decrease in the number of pores filled with water and an increase in the pores that were not filled with water. The MIP test shows that the volume and number of large pores decrease, and the volume and number of small pores increases along with the increase in nano-silica content, this is due to an increase in compressive strength ${ }^{[18]}$.

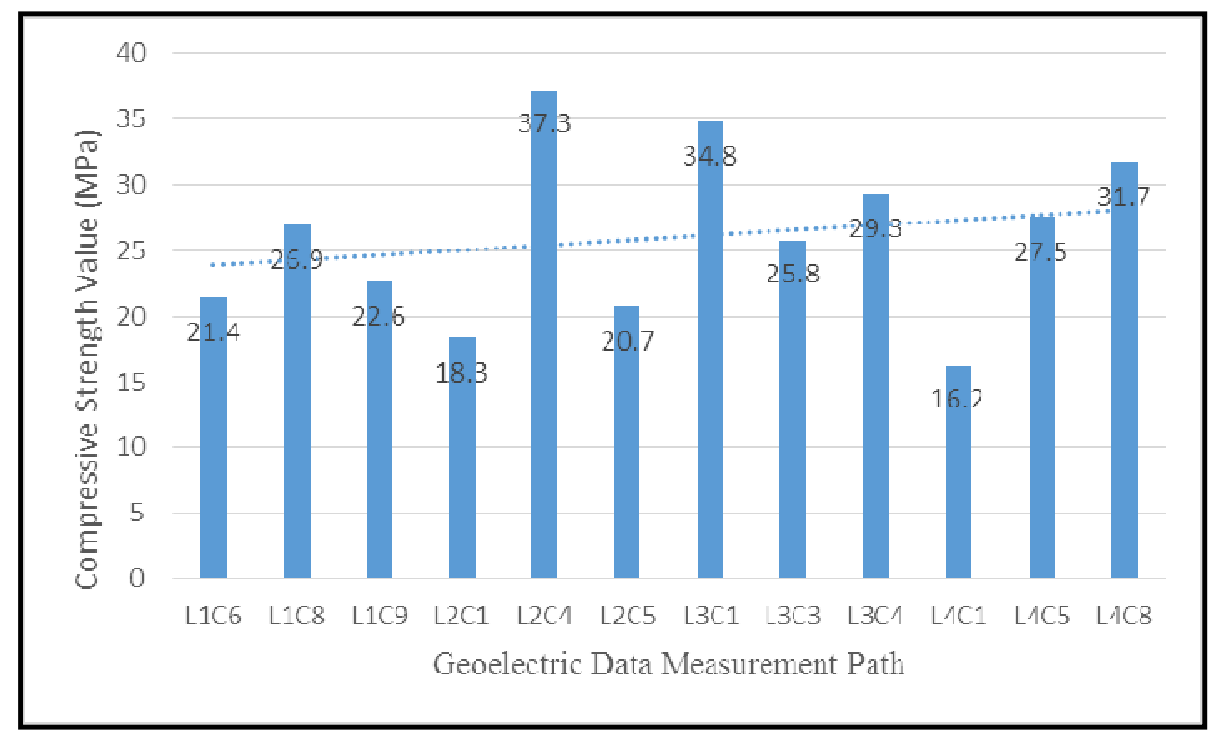

Figure 3. Comparison of compressive strength on cracks

Comparison of all paths in the compressive strength test is line 4 cracks 1 the lowest and line 2 cracks 4 the highest, the lower the compressive test, the faster landslides will occur (Figure 3), this happens because of water in the cracks, the number of cracks cavity and the density of the cracks. The decrease in compressive strength is strongly influenced by the ratio of the volume of water in the cracks. The higher the volume of water, the less the mass of cracks that can withstand the landslide rate. This results in reduced adhesion between the cracks holding layers. The decrease in compressive strength was also caused by the varying shape of the cracks which caused water to enter more freely, thus affecting the adhesion and power interlocking between the cracks holding layers.

\section{CONCLUSION}

Line 1 has 10 cracks, line 2 has 9 cracks, line 3 has 5 cracks, line 4 has 8 cracks. The more cracks, the higher the intensity of landslides, so for this study the landslide-prone zone is located on the line 1 stretch with a cross between the upper and lower soil layers. These rock crosses are rocks from the weathering of quartz rock into sandstone and claylimestone.

The results of the low compressive strength test resulted in landslides due to the presence of water in the cracks, the number of cracks cavities, and the density of the cracks, this 
resulted in reduced adhesion between the cracks retaining layers and a decrease in the number of pores filled with water and increased pores. which has not been filled with water.

\section{ACKNOWLEDGMENTS}

Thanks to the Ministry of Research, Technology, and Higher Education who provided funding, support, and guidance for this research.

\section{REFERENCES}

1 Susilo, A., Fitriah, F., Rachmawati, E. T. A., \& Suryo, E. A. 2020. Analysis of landslide area of Tulung subdistrict, Ponorogo, Indonesia in 2017 using resistivity method. Smart and Sustainable Built Environment, pp. 1-21.

2 Permana, R. S., Buana, A. P., Akmam, A., Amir, H., \& Putra, A. 2020. Using the Schlumberger configuration resistivity geoelectric method to estimate the rock structure at landslide zone in Malalak agam. Journal of Physics: Conference Series, Vol. 1481, No. 1, pp. 1-9.

3 Szalai, S., Prácser, E., Szokoli, K., \& Tóth, Á. 2017. Prediction of the process of a slowly moving loess landslide by electrical resistivity tomography. Adv. Cult. Living with Landslides, vol. 116, no. 26, pp. 131-138.

4 Lajaunie, M., Gance, J., Nevers, P., Bertrand, C., \& Malet, J. P. 2018. 3D Geoelectrical study of the Séchilienne Landslide: new constraints on the large scale water flow. EGU Gen. Assem, Vol. 20, pp. 16272.

5 Chen, Q., Zhang, S., Chang, S., Liu, B., Liu, J., \& Long, J. 2019. Geophysical Interpretation of a Subsurface Landslide in the Southern Qinshui Basin. J. Environ. Eng. Geophys., vol. 24, no. 3, pp. 433-449.

6 Adamo, N., Al-Ansari, N., Sissakian, V., Laue, J., \& Knutsson, S. 2021. Geophysical Methods and their Applications in Dam Safety Monitoring. J. Earth Sci. Geotech. Eng., Vol. 11, pp. 291-345.

7 Bellanova, J., Calamita, G., Giocoli, A., Luongo, R., Perrone, A., Lapenna, V., \& Piscitelli, S. 2016. Electrical Resistivity Tomography surveys for the geoelectric characterization of the Montaguto landslide (southern Italy). Nat. Hazards Earth Syst. Sci. Discuss, pp. 1-17.

8 Kieu, D. T., Pham, N. D., \& Lai, H. P. 2019. Integration of geoelectrical and seismic refraction data by means of fuzzy clustering for landslide investigation. EAGE-GSM 2nd Asia Pacific Meet. Near Surf. Geosci. Eng., no. April 2019, pp. 1-5.

9 Ariyanto, S. V., \& Joni, I. 2019. Zone Landslide Analysis Using Geophysical Method and Analysis of Soil Type for Disaster Mitigation In Waru Pamekasan. Indonesian Journal Of Applied Physics, Vol. 9, No.2, 68.

10 Deng, Y., Yan, S., Scaringi, G., Liu, W., \& He, S. 2020. An empirical power density-based friction law and its implications for coherent landslide mobility. Geophys. Res. Lett, Vol. 47, No. 11, pp. 1-9.

11 Setyawan, A., Fikri, M. S., Suseno, J. E., \& Fuad, M. 2018. Lithology and characteristic of landslide in Gombel Hill by 2D geoelectric resistivity method using dipole-dipole configuration. J. Phys. Conf. Ser, Vol. 1025, No. 1, pp. 1-9.

12 Dalimunthe, Y. K., \& Hamid, A. 2018. Georadar and geoelectricity method to identify the determine zone of sliding landslide. IOP Conf. Ser. Earth Environ. Sci, Vol. 106, No. 1, pp. 1-7.

13 Prawira, G. A., Arphan, F., \& Warnana, D. D. 2020. Integrated Geophysical Methods to Determine Subsurface Structure of PSK-1 Mini Hydro Power Plant, Citeurep Creeping Area. IOP Conf. Ser. Earth Environ. Sci, Vol. 479, No. 1 
14 Nurdin, N. H., Massinai, M. A., \& Arsyad, A. 2019. Identification of Landslide Potential using Electrical Resistivity Tomography Method Wenner-Schlumberger Configuration in Sampiro, Bolaang Mongondow Utara, North Sulawesi. J. Phys. Conf. Ser, Vol. 1341, No. 8, pp. 58-61.

15 A. N. Piller. 2016. Precipitation Intensity Required for Landslide Initiation in Rwanda.

16 Abija, F. A., Nwosu, J. I., Ifedotun, A. I., \& Osadebe, C. C. 2019. Landslide susceptibility assessment of Calabar, Nigeria using Geotechnical, Remote Sensing and Multi-Criteria Decision Analysis: Implications for urban planning and development. SDRP J. Earth Sci. Environ. Stud, Vol. 4, No. 6, pp. 774-788.

17 Ko, F. W., \& Lo, F. L. 2018. From landslide susceptibility to landslide frequency: A territory-wide study. Eng. Geol, Vol. 242, pp. 12-22.

$18 \mathrm{Hu}, \mathrm{K}$. , Chen, X., Chen, J., \& Ren, X. (2018). Laboratory investigation of the effect of nano-silica on unconfined compressive strength and frost heaving characteristics of silty clay. Soil Mech. Found. Eng, Vol. 55, No. 5, pp. 352-357. 